\title{
Recruitment and Selection Strategies and Practices in the Private Sector Commercial Banks of Bangladesh: Evidence from Human Resource Practitioners
}

\author{
Tamanna Parvin Eva \\ Department of Business Administration, East West University, Dhaka, Bangladesh \\ Email address: \\ tamanna_mgt@yahoo.com \\ To cite this article: \\ Tamanna Parvin Eva. Recruitment and Selection Strategies and Practices in the Private Sector Commercial Banks of Bangladesh: Evidence \\ from Human Resource Practitioners. European Business \& Management. Vol. 4, No. 1, 2018, pp. 28-38. doi: 10.11648/j.ebm.20180401.15
}

Received: November 17, 2017; Accepted: December 6, 2017; Published: January 8, 2018

\begin{abstract}
Effective organizational performances rely on the proper allocation of human resources in different functional areas. Proper recruitment and selection procedure helps an organization to allocate right type of qualified employees in the proper job position for ensuring organizational effectiveness. The banking sector is playing a crucial role in the economic advancement of Bangladesh through generating job opportunities and recruiting huge number of candidates in each year. Different researchers have projected different sources, methods, models and theories in light of designing effective recruitment and selection program. However, there is no analytical study on recruitment and selection strategies and practices in the private sector commercial banks of Bangladesh till date. The aim of the study is to fill the gap with identifying mostly used recruiting sources, selection methods, developing a selection model for the entry-level position along with identifying perceived major barriers and strategies for maintaining the effectiveness of recruitment and selection practices. Both qualitative and quantitative approaches have been followed to complete this study. Data have been collected from both primary and secondary sources. Primary data have been collected from Human Resource practitioners of 14 private commercial banks through using a wellstructured questionnaire with the inclusion of both open-ended and close-ended questions. Statistical analysis software SPSS20 version has been used for quantitative analysis. Major findings of the study are maximum banks have different preference level for using recruitment sources and selection methods. They follow different selection procedure for the entry-level vacant positions. There are also notable commonalties in using job analysis, some recruitment sources and selection methods, assigning primary and final hiring decision responsibilities to Human Resource Managers and line managers, perceiving major challenges and adopting strategies for effective recruitment and selection functions. An attempt has been made to develop a comprehensive selection model for the entry-level position. Finally, some recommendations have been provided in this paper which will be beneficial for banks, human resources practicing organizations and for future research.
\end{abstract}

Keywords: Recruitment and Selection, Strategies, HR and Line Management, A Comprehensive Selection Model

\section{Introduction}

In the recent competitive job market, not only the job seekers are struggling for getting a suitable job but also organizations are striving for conducting effective recruitment and selection activities to place and retain highly qualified employees in the suitable position. An effective recruitment and selection program ensures a right number of qualified employees for achieving organizational strategic goals in a cost-effective way [1], [2]. A pool of competent employees helps in gaining competitive advantage with maintaining employees' high level of performance and commitment [3], [4] [5], [6]. Therefore, each organization should adopt proper recruitment and selection (R \& S) strategies and carefully practice those to place the right qualified employees in the suitable position for ensuring organizational effective performance and sustainability.

As a crucial contributor to the economy, banks are rigorously concerning about wealth maximization through providing prominent customer services. Providing better customer services depends on the available qualified employee within the bank. Werther and Davis [7] confirmed 
that organizational effectiveness depends on skilled and competent employees. Implementations of recruitment and selection functions are accurately relevant for banks to gain customer satisfaction through providing better qualitative services which ultimately ensures increased organizational growth and profitability along with high employee satisfaction, productivity and loyalty [8]. In Bangladesh, banks are recruiting employees for different positions as per provided policy of the Central bank. However, there are some differences in their recruitment and selection strategies and practices in terms of using recruitment sources, selection methods and perceived effectiveness. In this paper, an attempt has been made to analyze in detail about how banks are generating recruitment and selection strategies and practicing those to ensure organizational effectiveness.

The purpose of this paper is to examine the current scenario of recruitment and selection ( $\mathrm{R} \& \mathrm{~S}$ ) strategies and practices in the private sector commercial banks of Bangladesh from Human Resource Practitioners' perspectives. Precisely, this paper explores several particular queries like whether organizations conduct job analysis before giving vacancy advertisement for employment, whether they rely on recruiting agency, which recruitment sources and selection methods are commonly used, after occurring vacancies whether they consider existing employee first, how they select employees, whether recruitment and selection responsibilities are jointly held by both Human Resource Managers and line managers, how decentralization of these responsibilities to line managers are growing, what are the major barriers, which strategies they give most priority for ensuring effective recruitment and selection practices.

\section{The Rationale of the Study}

Few studies have been conducted regarding $\mathrm{R} \& \mathrm{~S}$ practices in the private sector commercial banks in Bangladesh. A case study on a bank indicated that this organization gives more importance to external sources, avoids employee referrals and prefers ability test and the structured interview for recruiting employees [9]. In a comparative analysis on overall HRM practices of 2 public and 2 private banks found that private banks are more concern about the selection process of Management Trainee Officer (MTO) position and compensation packages whereas public banks are giving value to the presence of trade unions and timely promotion [10]. In a study on manufacturing firms revealed that the private sector is fair enough in conducting job analysis and selection process than the public sector firms, yet there is no significant difference in overall recruitment and selection process in both manufacturing sectors [11]. Another study on recruitment and selection practices form employee perspectives showed that bank prefers external sources than internal sources with giving importance on educational background, skills and work experiences [12].

It is evident that there is an absence of the research on detail analysis of recruitment and selection strategies and practices in the private sector commercial banks in
Bangladesh from HR perspectives. Hence, it is expected that this study will add some learning on the detail procedure of recruiting activities in Bangladesh context and fill the study gap moderately.

\section{Literature Review}

Recruitment is the systematic process of discovering and inviting a large number of prospective competent candidates through informing the market to fill the vacant job positions timely [8]. It comprises of determining available jobs, collecting information from job description and job specifications for giving advertisement [2]. Selection is the procedure of collecting and evaluating qualified candidates' information and picking suitable candidates from the candidates' pool whose qualification meet the job requirement to place in the vacant position [2]. The aim of selection task is acquiring the right employee for the right position, establishing and retaining employer's reputation in the market and ensuring cost-effective selection process [2], [13].

\subsection{Importance of Job Analysis}

Job analysis plays an important role in recruitment and selection activities as it gives a clear set of information about job requirement which helps to identify the fitness of a job into the overall job structure and to decide what type of individual should be appointed [14]. Organizations should prepare job specifications for the vacant positions and then strictly follow those during recruitment and selection of employees [15]. Based on nature of jobs, different types of recruitment sources and selection methods a variety of approaches and preferences could be used for ensuring diversity in an organization [16], [17]. "The majority of HR managers revealed that if a job description and person specification were not available for the vacant position, the relevant heads of departments had to prepare these with the help of the HR department before commencing recruitment" [18].

\subsection{Recruitment Sources}

Organizations select the recruitment approach based on nature of job status, company reputation, availability of personnel in the recruitment group and the recruitment budget [19]. Direct mail and employee referrals are very prompt to attain candidates' response than the newspaper job advertisement [20], [21]. Formal sources of recruitment like job advertisement in newspapers and posters are less beneficial than the informal sources like walk-ins, internal job posting, employee referrals and rehiring previous employees because these sources deliver correct and comprehensive information about candidates' knowledge and competencies [22]. To execute recruitment strategies successfully, maximum organizations may use two or more styles from different categories of recruitment methods like job advertisement, referrals by existing employees, campus recruitment, agency or expert involvement, job boards, organizational websites, social media etc. [19]. Banks may 
use sources like existing employee recommendations, educational institutes, head hunter firms, self-web pages for communicating with prospective employees [8]. Erecruitment or the use different sophisticated technologies in recruitment and selection function become very prevalent [23], [24]. In the family business, the informal approach like word-of-mouth is beneficial to maintain relationship and friendship [16], [25]. Other forms of external recruiting sources such as advertisements and employment agencies or consultants are also popular [24].

\subsection{Selection Strategies}

Uses of selection strategies may differ based on types of jobs. The selection process of non-managerial position is also differing from managerial selection process [26]. Selection strategy of an organization will be effective if suitable persons are selected by focusing suitable combination of skills as per job requirement [27]. Organizations may practice from the available set of selection methods such as completed application form, assessment centers, work sampling test, aptitude or work ability test, mental ability test, face to face individual or panel interview, medical examination, reference check etc. [18], [28]. Employee selection methods include initial screening of prospective candidates, conducting a test, arranging interviews, choosing applicants based on test or interview scores and placing them to certify that they will be capable to accomplish their assigned roles effectively [21]. The interview is the most common selection method because of its easy execution, quick outcome and cost-effectiveness [29], [30]. Evaluation of applicants' employment record or resumes, written application and reference checks are also widely used selection tools [22], [30], [31]. The situational based test is more useful than the personality and mental ability test [32].

Bank employees should be selected through personality test for assessing candidates' traits of diligence, sociability, sensitivity, eagerness to learn, self-confidence, compassion, self-efficacy etc. to ensure better customer service [8]. During selection, necessary qualifications like communication capabilities, leadership qualities, motivation level, analytical abilities and managerial capabilities need to be focused [30], [33]. Some organizations also give importance to innovativeness and experiences [31].

\subsection{Role of HR Managers and Line Managers}

Successful recruitment and selection functions could be completed with the combined effort of Line managers and HR managers [28], [31], [33]. Cooperation between HR Managers and line managers are necessary during final selection decision to make the selection program effective as the line manager know better about direct employees [16]. The delegation of recruitment and selection responsibility has been increased to line managers as Human Resource managers are tend to be more engaged in formulating and implementing HR strategies linked with the business level strategies [16], [34]. Line managers are playing an important role in case of final selection decision while HR manager's main duty is to assist and cooperate with line managers not to control their functions [16].

\subsection{Effective Recruitment and Selection Strategies}

Assessing recruitment and selection effectiveness is very difficult as different organizations have different evaluation techniques [35]. The effectiveness could be analyzed through viewing procedural justice, clarity, gender matters, the role of line management, human resources competencies level, and impact of both organizational and country politics [36]. Recruitment effectiveness depends on execution time and media or channel of recruitment which are best suitable [19]. Predominantly effectiveness can be assessed through investigating turnover rate, survival rate, and employees' performance accompanied by managerial issues of employee referrals, internal job posting, and re-hiring of previous employees [22]. Quality of the recruitment process during recruitment time is crucial to hire right qualified applicants for the right position [19], [37]. Chances of getting the right type of person for the vacant position not only depend on the application of appropriate selection methods but also on the usage of proper criteria for selection [38]. For conducting successful selection program managers need to recognize purposes, strategies and practices of this program [39].

\subsection{Impact of Recruitment and Selection Strategies}

Overall organizational performance and its reputation positively influenced by the effective execution of recruitment and selection functions [6]. Organizational achievements and existence greatly rely on effective practices of these functions as they are the vital part corporate level strategies [1]. Comprehensive recruitment, valid selection test, proper selection process and organizational profits are positively related [40]. Uses of proper approach or style can lead to getting good quality employees which in turn give the better organizational performance [41]. Reliability and validity of a selection instruments have a significant effect on getting desirable qualified and skilled employees [38]. Selected best employees for the specific position ensure efficient performance [42]. Customer satisfaction and loyalty in the service sector could be gained by qualified and competent employees who need to be collected through practicing suitable recruitment and section procedure [43].

\subsection{Barriers to Recruitment and Selection Practices}

For being organizational recruitment and selection functions failure, there are some major problems like lack of interconnection between recruitment and selection strategies along with HR strategies and corporate strategies, insufficiency of job analysis data, absent of key information details from the advertisement, vague interview arranged and application usage, inappropriate use of psychological testing, improper verification of psychometrics test, application of inappropriate selection methods, absence of scrutinizing the recruitment and selection procedure, poor measurement of 
orientation programs, lack of corrective actions after examining the recruiting practices and invalid situational test [44]. Lack of formal valid selection system and absence of experienced Human Resource Specialists are also major barriers to recruitment and selection practices [30], [45]. Other common barriers in recruitment and selection practices are improper human resource planning, the absence of comprehensive and vigorous recruiting strategies along with the process and selection criteria, the nonexistence of HR department, unavailability of HR experts and lack of dedication of HR team [46]. Lack of integration between business strategies and recruiting strategies, unavailability of qualified applicants in the market, ineffective job analysis, inappropriate selection tool and the absence of line managers' contribution in the recruiting session are also important barriers [47].

\section{Theoretical Framework}

This paper has been constructed based on Equity theory and Resource-Based View theory to examine the overall R \& $\mathrm{S}$ strategies and practices in the private sector banks of Bangladesh. Equity theory has emphasized on the code of justice which depicts that organizations should organize and practice the best suitable recruiting principles to be an Equal Employment Opportunity (EEO) provider [48]. Resource Based View theory has highlighted on the use of proper selection criteria for hiring the right type of person in the suitable position for generating inimitable qualified pool of human resources whose competence will strongly influence to increase strength and decrease weaknesses to gain competitive advantage [49]. Organizations can produce human resource advantage if they adopt proper recruitment and retention strategies for having exceptional employees [50]. As attaining an equipped pool of highly competent and motivated employees is more difficult than technologies and capital, therefore organization should be very cautious during recruitment and selection practices to make them unique [51], [52].

\section{Research Methodology}

Mix method approach of both quantitative and qualitative has been followed to complete this study. Purposive sampling procedure has been followed to collect detailed information from 14 private commercial banks in Bangladesh among 39 Dhaka Stock Exchange (DSE) listed commercial banks. For research work sample size of at least $30 \%$ is acceptable [53], [54]. This paper has been completed with adopting a sample size of $36 \%$ which is usually acceptable.

To complete this study both primary and secondary data have been collected. For collecting primary data, a structured questionnaire including both open ended and close ended questions has been used. Information from literature review has been used to administer the questionnaire. The 5-point Likert scale of "Not used" to "Frequently used" for collecting information about recruitment sources and selection methods, "Strongly disagree" to "Strongly agree" for getting data about major challenging and effective recruiting factors have been applied in the questionnaire. In-depth interviews have been taken from HR personnel of selected 14 commercials banks through sending the developed questionnaire. A set of 80 questions has been incorporated to acquire precise and judgment based data with stating 'When', 'Which' and 'How' investigating type questions which have been segmented into broad 5 parts. These parts include questions related to recruitment and selection system, queries related to the level of using different sources and selection methods, level of consent for several factors which create barriers and which ensure effectiveness. Data has been analyzed by using descriptive statistics such as frequency counts and percentages. Chi-square goodness of fit test has also been used to test the significant differences in practices of all banks through using Statistical Analysis Software SPSS 20.

\section{Data Analysis and Findings}

\subsection{Sample Characteristics}

A total of 15 respondents' answers from selected 15 banks have been collected. But 14 responses were accepted from 15 responses as there were no missing answers. The first part of the questionnaire includes responders basic profile information like experience in HR practice, service duration in the current organization, age, gender, educational background etc. which have been recognized for collecting factual information about recruitment and selection strategies and practices in their organizations. Responders' basic profiles are presented below (Table 1):

Table 1. The basic profile of respondents.

\begin{tabular}{lll}
\hline Parameters & Classifications & Percentage (\%) \\
\hline \multirow{2}{*}{ Respondents' Age } & 25 to 34 & 42.9 \\
& 35 to 44 & 50 \\
Gender & 45 to 54 & 7.1 \\
Educational qualification & Male & 92.9 \\
& Female & 7.1 \\
Experience in HR practice & MBA/Masters & 100 \\
& Less than 5 years & 28.6 \\
& 5 to 10 years & 57.1 \\
Length of service in the current organization & 11 to 15 years & 14.3 \\
& Less than 5 years & 28.6 \\
& 6 to 10 years & 64.3 \\
\hline
\end{tabular}




\subsection{Reliability Test}

Cronbach's Alpha has been used to the Likert scale questions reliability for assessing all scales. Reliability coefficient is acceptable when scores are more than 0.70 (Nunnally, 1978). SPSS has been used to test the reliability. Reliability scores were for recruitment sources 0.770 , selections methods 0.710 , and major barriers and strategies for effective recruitment and selection 0.733 which exceed the acceptable limit of 0.70 . Hence, it could be concluded that all variables scale of the questionnaire survey presented a good reliability.

\subsection{Recruitment Policy, Job Analysis and Involvement of Line Management}

The survey discovers that $100 \%$ of the respondent banks have a formal written policy to guide the overall recruitment and selection functions. It also reveals that $100 \%$ respondents use job analysis information to complete the recruiting purposes. $92.9 \%$ respondents mentioned that their organizations always give job advertisement publicly whenever vacancies occurred while $7.1 \%$ stated that they do not always give the public announcement. A majority of the respondents (85.7\%) mentioned that their organizations consider existing employees first for filling vacant positions. $57.14 \%$ respondents reported that banks do not appreciate the involvement of recruiting agency for conducting the recruitment and selection activities while $21.43 \%$ agreed that they prefer agencies involvement and $21.43 \%$ also mentioned that sometimes they take help from recruiting agencies. In regarding the primary responsibility of recruitment and selection task, $71.43 \%$ respondents confirmed that HR department completes the total process in consultation with the line management, $14.29 \%$ reported that solely HR department completes the process while $14.29 \%$ conveyed that line management completes the process in consultation with $\mathrm{HR}$ department. Line management involvement in the recruitment and selection practices has been increased over the last three years as reported by $71.43 \%$ respondents, while $21.43 \%$ conveyed that it is same and $7.14 \%$ stated that it has been decreased.

\subsection{Uses Level of Different Recruitment Sources}

Table 2. Recruitment sources used by different selected banks in Bangladesh.

\begin{tabular}{|c|c|c|c|c|c|c|c|c|c|c|}
\hline \multirow{3}{*}{ Sources } & \multicolumn{10}{|c|}{ Respondents' preferences } \\
\hline & \multicolumn{2}{|c|}{ Not Used } & \multicolumn{2}{|c|}{ Sometimes Used } & \multicolumn{2}{|c|}{ Average Used } & \multicolumn{2}{|c|}{ Frequently Used } & \multicolumn{2}{|c|}{ Most Frequently Used } \\
\hline & Freq & $\%$ & Freq & $\%$ & Freq & $\%$ & Freq & $\%$ & Freq & $\%$ \\
\hline Present employees or Internal recruitment & - & - & 4 & 28.6 & 4 & 28.6 & 4 & 28.6 & 2 & 14.3 \\
\hline Company website & & & 2 & 14.3 & 2 & 14.3 & 3 & 21.4 & 7 & 50 \\
\hline Internet recruitment & 2 & 14.3 & 3 & 21.4 & 1 & 7.1 & 2 & 14.3 & 6 & 42.9 \\
\hline TV/Radio advertisement & 9 & 64.3 & 2 & 14.3 & 2 & 14.3 & 1 & 7.1 & - & - \\
\hline Local Newspaper advertisement & - & - & 4 & 28.6 & 2 & 14.3 & 4 & 28.6 & 4 & 28.6 \\
\hline Employee referrals & - & - & 4 & 28.6 & 4 & 28.6 & 6 & 42.9 & - & - \\
\hline Professional association (s) & 2 & 14.3 & 7 & 50 & 2 & 14.3 & 1 & 7.1 & 2 & 14.3 \\
\hline Employment agents & 2 & 14.3 & 7 & 50 & 3 & 21.4 & 2 & 14.3 & - & - \\
\hline Word of Mouth & 6 & 42.9 & 6 & 42.9 & 1 & 7.1 & 1 & 7.1 & - & - \\
\hline Job fairs/ Campus recruitment & 4 & 28.6 & 5 & 35.7 & 3 & 21.4 & 1 & 7.1 & 1 & 7.1 \\
\hline Direct mail to prospective candidates & 7 & 50 & 4 & 28.6 & 1 & 7.1 & 2 & 14.3 & - & - \\
\hline Talent hunting & & & 5 & 35.7 & 1 & 7.1 & 6 & 42.9 & 2 & 14.3 \\
\hline Unsolicited applications & 9 & 64.3 & 4 & 28.6 & 1 & 7.1 & - & - & - & - \\
\hline
\end{tabular}

The above descriptive analysis discovered that the uses level of different recruitment sources varies from organizations to organizations. Two separate lists of commonly used and least used of recruitment sources can be developed. Commonly used methods have been selected based on total percentage of average used, frequently used and most frequently used whereas least used sources have been selected based on total percentage of not used and sometimes used sources. Average used to most frequently used recruitment sources are internal recruitment $(71.5 \%)$, company website $(85.7 \%)$, internet recruitment or erecruitment (64.3\%), local Newspaper advertisement (71.5\%), employee referrals (71.5\%), talent hunting (64.3\%) while not used and sometimes used sources are TV/Radio advertisement (78.6\%), professional association (64.3\%), Word of Mouth (85.8\%), job fairs/ campus recruitment $(64.3 \%)$, Direct mail to prospective candidates $(78.6 \%)$, Unsolicited applications (or Walk-ins/Write-ins) (92.8\%). So, a list of recruitment sources has been developed which is given below: 


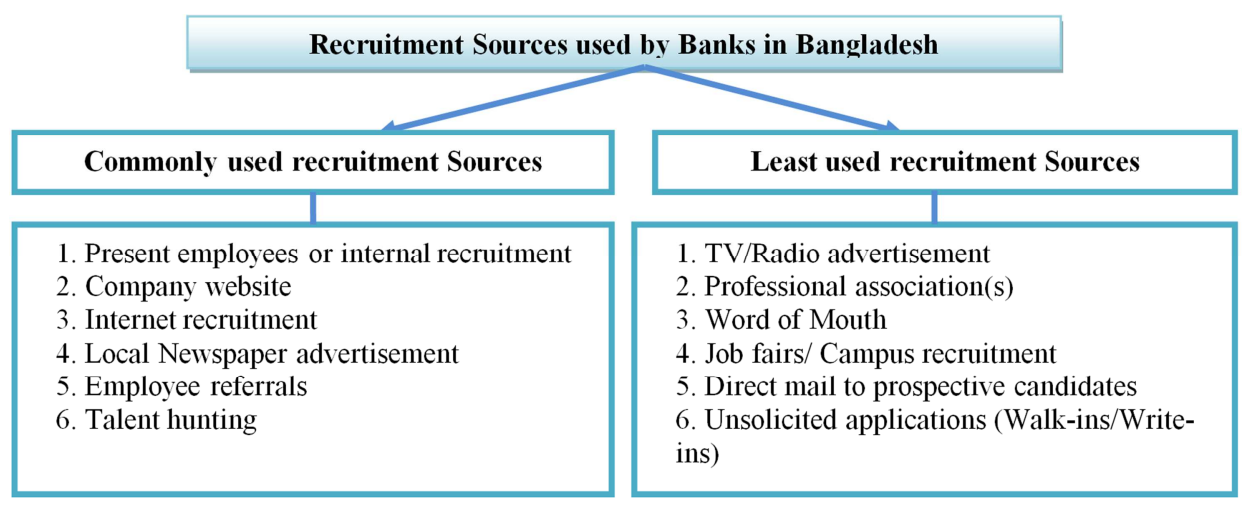

Figure 1. List of recruitment sources.

\subsection{Recruitment Sources Are Equally Preferable or Not to All Respondent Organizations}

When all banks preferences regarding uses level of recruitment sources have been compared, the result shows that there are significant differences for using recruiting methods of company website (p-value0.000), internet recruitment (p-value0.000), local newspaper advertisement (p-value 0.015), employee referrals (p-value 0.009), professional association (s) (p-value 0.012), employment agents (p-value 0.032 ), word of mouth (p-value 0.050 ), and talent hunting (p-value 0.000), except methods of internal recruitment ( $\mathrm{p}$-value 0.385), campus recruitment ( $\mathrm{p}$-value 0.269 ), direct mail to prospective candidates ( $\mathrm{p}$-value 0.455 ), $\mathrm{TV} /$ radio advertisement ( $\mathrm{p}$-value 0.405) and unsolicited applications (p-value0.368) as per the significant level of 0.05 . So, it can be concluded that all banks have the similar level of preferences (as p-value >0.05) for using the recruiting methods of internal recruitment, campus recruitment, direct mail to prospective candidates, TV/radio advertisement and unsolicited applications.

\subsection{Preference Level of Using Selection Methods}

Table 3. Selection methods used by different selected banks in Bangladesh.

\begin{tabular}{|c|c|c|c|c|c|c|c|c|c|c|}
\hline \multirow{3}{*}{ Methods } & \multicolumn{10}{|c|}{ Respondents' preferences } \\
\hline & \multicolumn{2}{|c|}{ Not Used } & \multicolumn{2}{|c|}{ Sometimes Used } & \multicolumn{2}{|c|}{ Average Used } & \multicolumn{2}{|c|}{ Frequently Used } & \multicolumn{2}{|c|}{ Most Frequently Used } \\
\hline & Freq & $\%$ & Freq & $\%$ & Freq & $\%$ & Freq & $\%$ & Freq & $\%$ \\
\hline $\begin{array}{l}\text { Submitting applications with presenting key information } \\
\text { of education/ work experience }\end{array}$ & - & - & - & - & 2 & 14.3 & 4 & 28.6 & 8 & 57.1 \\
\hline Ask for Curriculum vitae along with application & - & - & - & - & 1 & 7.1 & 5 & 35.7 & 8 & 57.1 \\
\hline References check & - & - & 1 & 7.1 & 3 & 21.4 & 4 & 28.6 & 6 & 42.9 \\
\hline Personal profile or biographical data checking & - & - & 2 & 14.3 & 3 & 21.4 & 6 & 42.9 & 3 & 21.4 \\
\hline $\begin{array}{l}\text { Ability tests to measure mental, clerical, mechanical, } \\
\text { physical or technical abilities }\end{array}$ & - & - & - & - & 3 & 21.4 & 6 & 42.9 & 5 & 35.7 \\
\hline Knowledge tests to measure the job-specific knowledge & - & - & - & - & 2 & 14.3 & 5 & 35.7 & 7 & 50 \\
\hline $\begin{array}{l}\text { Performance test under structured challenging } \\
\text { circumstances }\end{array}$ & 1 & 7.1 & 3 & 21.4 & 2 & 14.3 & 5 & 35.7 & 3 & 21.4 \\
\hline Use of Assessment centres (role plays and simulation) & - & - & 4 & 28.6 & 4 & 28.6 & 3 & 21.4 & 3 & 21.4 \\
\hline $\begin{array}{l}\text { Behavioral interviews to ascertain specific samples of } \\
\text { their skills }\end{array}$ & 1 & 7.1 & 1 & 7.1 & 2 & 14.3 & 7 & 50 & 3 & 21.4 \\
\hline $\begin{array}{l}\text { Situational interviews to ascertain actions in anticipated } \\
\text { situations }\end{array}$ & - & - & 2 & 14.3 & 2 & 14.3 & 7 & 50 & 3 & 21.4 \\
\hline Personality and interest test & - & - & - & - & 4 & 28.6 & 6 & 42.9 & 4 & 28.6 \\
\hline $\begin{array}{l}\text { Aptitude tests of numerical and verbal reasoning, in-tray } \\
\text { exercises, situational judgment, inductive reasoning and } \\
\text { cognitive ability }\end{array}$ & - & - & 2 & 14.3 & 1 & 7.1 & 3 & 21.4 & 8 & 57.1 \\
\hline Face to face individual interview & - & - & - & - & 1 & 7.1 & 3 & 21.4 & 10 & 71.4 \\
\hline Group interview & 3 & 21.4 & 6 & 42.9 & 2 & 14.3 & 1 & 7.1 & 2 & 14.3 \\
\hline Medical examination to test physical fitness & - & - & - & - & 1 & 7.1 & 4 & 28.6 & 9 & 64.3 \\
\hline
\end{tabular}

The above descriptive analysis discovered that the uses level of different selection methods also varies from organizations to organizations. Commonly used methods have been selected based on total percentage of average used, frequently used and most frequently used as like as recruitment sources. So commonly used selection methods are submitting applications $(100 \%)$, ask for curriculum vitae (100\%), references check (92.9\%), checking biographical data $(85.7 \%)$, evaluation of training and experiences $(85.7 \%)$, ability tests $(100 \%)$, knowledge tests $(100 \%)$, performance 
test $(71.5 \%)$, use of Assessment centres $(71.4 \%)$, behavioral interviews $(85.7 \%)$, situational interviews $(85.7 \%)$, personality and interest test $(100 \%)$, aptitude tests $(85.7 \%)$, face to face individual interview (100\%), medical examination $(100 \%)$ while not used and sometimes used source is only group interview (64.3\%).

\subsection{Selection Methods Are Equally Preferable or Not to All Respondent Organizations}

During comparison of all banks preferences regarding uses level of selection methods the result shows that there are significant differences for using selection methods of submitting application forms (p-value 0.000), curriculum vitae along with application (p-value 0.000), reference check (p-value0.000), checking personal profile (information about family, hobbies, attitudes etc.) (p-value 0.012), training and experiences evaluation ( $p$-value 0.001 ), knowledge test ( $p$ value 0.000$)$, performance test (p-value 0.010$)$, behavior based interview (p-value 0.000), situational interview ( $p$ value 0.000 ), aptitude test ( $p$-value 0.000 ), face to face interview ( $p$-value 0.000), group interview ( $p$-value 0.000) and medical examination ( $\mathrm{p}$-value 0.000 ) except ability test (p-value 0.144), assessment centers (significance 0.771), personality and interest test ( $p$-value 0.320 ) as per the significant level of 0.05 . So it could be concluded that all banks have the similar level of preferences (as p-value $>0.05$ ) for selection methods of ability test, assessment centers, personality\& interest test.

\subsection{The Selection Process for Entry Level Position}

Respondents were asked to rank each task of selection program as per the practice of their respective organizations to identify the specific selection process employed by them. Probable selection tasks are (a) completed application form (CAF) or submitting CV, (b) Initial Screening of candidates (IS), (c) Preliminary Interview (PI), (d) Employment Test like ability, interest, aptitude test (ET), (e) Written Examination (WE), (f) Comprehensive face to face Interview (CI), (g) Background investigation \&Reference Check, (h)Medical Examination.

Table 4. Selection Process practiced by different selected banks in Bangladesh.

\begin{tabular}{|c|c|c|c|}
\hline & \multirow{2}{*}{ Ways of Selection Process } & \multicolumn{2}{|c|}{ Respondents' preferences } \\
\hline & & Frequency & Percentage \\
\hline A & CAF $\sigma \mathrm{IS} \varpi \mathrm{WE} \sigma \mathrm{CI} \sigma \mathrm{RC} \sigma \mathrm{ME} \sigma \mathrm{JO}$ & 3 & 21.4 \\
\hline B & $\mathrm{CV} \circlearrowleft \mathrm{IS} \sigma \mathrm{WE} \sigma \mathrm{ET} \sigma \mathrm{CI} \sigma \mathrm{RC} \odot \mathrm{ME} \odot \mathrm{JO}$ & 5 & 35.7 \\
\hline $\mathrm{C}$ & $\mathrm{CAF} \sigma \mathrm{IS} \sigma \mathrm{PI} \sigma \mathrm{WE} \sigma \mathrm{CI} \sigma \mathrm{ME} \sigma \mathrm{RC} \sigma \mathrm{JO}$ & 5 & 35.7 \\
\hline $\mathrm{D}$ & $\mathrm{CV} \approx \mathrm{WE} \approx \mathrm{CI} \sim \mathrm{JO}$ & 1 & 7.1 \\
\hline
\end{tabular}

The frequency distribution and percentage analysis result show that four different selection process practiced by different organizations. The Chi-square test analysis result revealed that selection process practiced by different banks in Bangladesh are significantly different as p-value is less than the Alpha value $(\mathrm{p}=0.008<0.05)$. Therefore based on the above four alternative selection processes a comprehensive model of the selection process can be developed which is presented below:

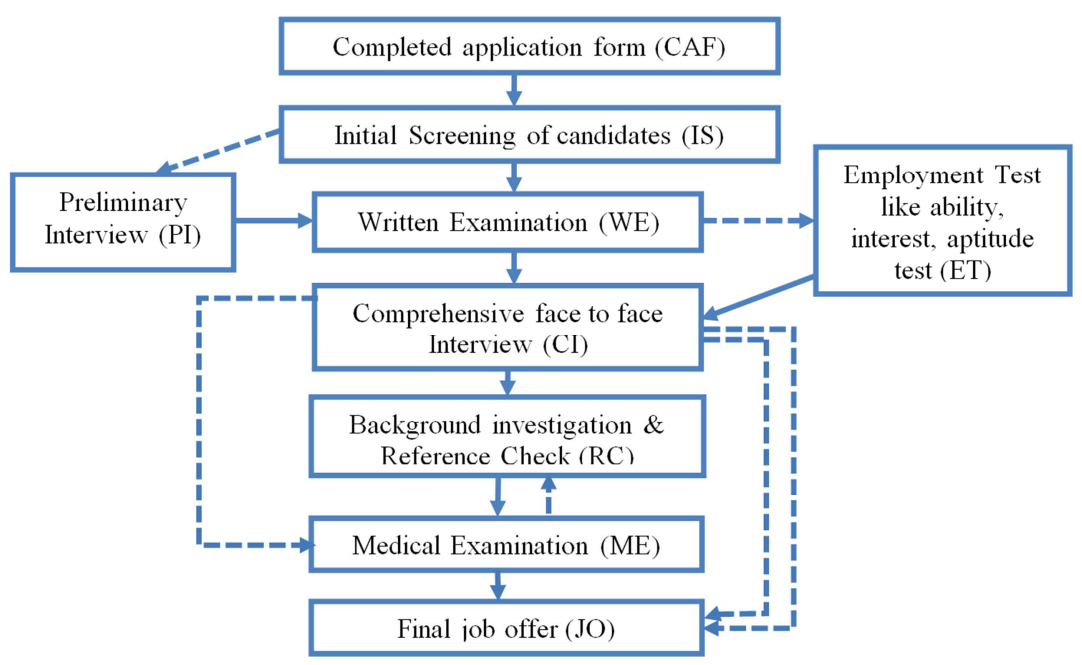

Figure 2. Comprehensive Model of Recruitment and Selection Process.

The comprehensive model shows that some organizations may follow the straight line process from completed application to final job offer whereas some organizations may adopt alternative steps (dotted arrow sign) of a preliminary interview after initial screening and then arrange written examinations, others may conduct employment test after written exam and then arrange the comprehensive interview. Some other organization may give job offer directly after the comprehensive interview whereas others may ask for medical examination report immediately after the comprehensive interview and then examine references to give final job offer. 


\subsection{Major Barriers to Effective Recruitment and Selection of Candidates}

Table 5. Reasons that create barriers to effective recruitment and selection functions.

\begin{tabular}{|c|c|c|c|c|c|c|c|c|c|c|}
\hline \multirow{3}{*}{ Particulars } & \multicolumn{10}{|c|}{ Respondents' preferences } \\
\hline & \multicolumn{2}{|c|}{ Strongly disagree } & \multicolumn{2}{|c|}{ Disagree } & \multicolumn{2}{|c|}{ Neutral } & \multicolumn{2}{|c|}{ Agree } & \multicolumn{2}{|c|}{ Strongly agree } \\
\hline & Freq & $\%$ & Freq & $\%$ & Freq & $\%$ & Freq & $\%$ & Freq & $\%$ \\
\hline Lack of proper HR planning & 2 & 14.3 & 1 & 7.1 & 2 & 14.3 & 5 & 35.7 & 4 & 28.6 \\
\hline Availability of fewer qualified applicants & 1 & 7.1 & 3 & 21.4 & 2 & 14.3 & 8 & 57.1 & - & - \\
\hline Difficulty in detecting qualified applicants & 1 & 7.1 & 2 & 14.3 & 1 & 7.1 & 8 & 57.1 & 2 & 14.3 \\
\hline Competition for the same applicants & - & - & - & - & 4 & 28.6 & 7 & 50 & 3 & 21.4 \\
\hline Slow Selection process & 1 & 7.1 & 3 & 21.4 & 6 & 42.9 & 3 & 21.4 & 1 & 7.1 \\
\hline Lack of experience in $\mathrm{R} \& \mathrm{~S}$ functions & - & - & - & - & 4 & 28.6 & 6 & 42.9 & 4 & 28.6 \\
\hline Ineffective job analysis & - & - & - & - & 1 & 7.1 & 10 & 71.4 & 3 & 21.4 \\
\hline Incomplete job advertisement & 2 & 14.3 & 3 & 21.4 & 1 & 7.1 & 5 & 35.7 & 3 & 21.4 \\
\hline Improper selection methods & - & - & 6 & 42.9 & 1 & 7.1 & 3 & 21.4 & 4 & 28.6 \\
\hline Too much agents' involvement & 3 & 21.4 & 3 & 21.4 & 2 & 14.3 & 4 & 28.6 & 2 & 14.3 \\
\hline Cost of R \& S of employees & - & - & 3 & 21.4 & 2 & 14.3 & 9 & 64.3 & - & - \\
\hline Poor working conditions & 3 & 21.4 & 3 & 21.4 & 1 & 7.1 & 3 & 21.4 & 4 & 28.6 \\
\hline Lack of employee awareness about R \& S criteria & 1 & 7.1 & 4 & 28.6 & 2 & 14.3 & 4 & 28.6 & 3 & 21.4 \\
\hline Location of available jobs & 1 & 7.1 & 5 & 35.7 & 3 & 21.4 & 3 & 21.4 & 2 & 14.3 \\
\hline
\end{tabular}

Different respondents have given different level of opinion regarding barriers to effective R \& S practices in banks. From the above analysis a list of major barriers in effective R \& S practices can be identified based on more than total $50 \%$ percentage of agree and strongly agree statements which are lack of proper human resource planning 64.3\%, availability of fewer qualified applicants $57.1 \%$, difficulty in detecting qualified applicants $71.4 \%$, competition for the same applicants $71.4 \%$, nostronglinkage with HR strategy and organizational goals $57.1 \%$, lack of experiences in recruitment and selection functions $71.5 \%$, ineffective job analysis $92.8 \%$, incomplete job advertisement $57.1 \%$, and cost of recruitment and selection $64.3 \%$.

\subsection{Strategies to Lead Effective Recruitment and Selection Practices}

Table 6. Strategies for ensuring effective and efficient recruitment and selection program.

\begin{tabular}{|c|c|c|c|c|c|c|c|c|c|c|}
\hline \multirow{3}{*}{ Statements } & \multicolumn{10}{|c|}{ Respondents' preferences } \\
\hline & \multicolumn{2}{|c|}{ Strongly disagree } & \multicolumn{2}{|c|}{ Disagree } & \multicolumn{2}{|c|}{ Neutral } & \multicolumn{2}{|l|}{ Agree } & \multicolumn{2}{|c|}{ Strongly agree } \\
\hline & Freq & $\%$ & Freq & $\%$ & Freq & $\%$ & Freq & $\%$ & Freq & $\%$ \\
\hline Specific and structured R\&S policies are important & - & - & - & - & - & - & 1 & 7.1 & 13 & 92.9 \\
\hline Huge applicants should encourage to apply & - & - & 2 & 14.3 & 4 & 28.6 & 4 & 28.6 & 4 & 28.6 \\
\hline Job analysis (JA) guides recruitment & - & - & - & - & - & - & 11 & 78.6 & 3 & 21.4 \\
\hline $\mathrm{JA}$ is the prior function of $\mathrm{R} \& \mathrm{~S}$ & - & - & - & - & 2 & 14.3 & 10 & 71.4 & 2 & 14.3 \\
\hline Proper JA can reduced $R \& S$ cost & - & - & - & - & 2 & 14.3 & 7 & 50 & 5 & 35.7 \\
\hline Selection should be fair & - & - & - & - & 1 & 7.1 & 3 & 21.4 & 10 & 71.4 \\
\hline $\begin{array}{l}\text { Both line \& HR manager should participate in the } \\
\text { selection process }\end{array}$ & - & - & - & - & - & - & 8 & 57.1 & 6 & 42.9 \\
\hline $\begin{array}{l}\text { Managers should spend considerable time in selection } \\
\text { process }\end{array}$ & - & - & 1 & 7.1 & 1 & 7.1 & 6 & 42.9 & 6 & 42.9 \\
\hline Applicants' psychological attributes should be focused & - & - & 2 & 14.3 & 1 & 7.1 & 7 & 50 & 4 & 28.6 \\
\hline $\begin{array}{l}\text { Written R\&S policies are important to motivate existing } \\
\text { employees to stay }\end{array}$ & 1 & 7.1 & - & - & 5 & 35.7 & 5 & 35.7 & 3 & 21.4 \\
\hline R\&S Policies should be updated & 2 & 14.3 & - & - & 6 & 42.9 & 4 & 28.6 & 2 & 14.3 \\
\hline $\begin{array}{l}\text { R \& S Policies should be related with organizational } \\
\text { policies and strategic goals }\end{array}$ & - & - & - & - & 1 & 7.1 & 7 & 50 & 6 & 42.9 \\
\hline $\begin{array}{l}\mathrm{R} \& \mathrm{~S} \text { Policies need to be changed based on } \\
\text { organizational policies }\end{array}$ & - & - & 1 & 7.1 & 3 & 21.4 & 8 & 57.1 & 2 & 14.3 \\
\hline $\begin{array}{l}\text { The chosen selection tool must be able to measure an } \\
\text { attribute consistently }\end{array}$ & - & - & - & - & 3 & 21.4 & 8 & 57.1 & 3 & 21.4 \\
\hline $\begin{array}{l}\text { Selection contents should be designed based on a job } \\
\text { relevant criterion }\end{array}$ & - & - & - & - & 4 & 28.6 & 8 & 57.1 & 2 & 14.3 \\
\hline Right employees should be placed in the right position & - & - & - & - & - & - & 3 & 21.4 & 11 & 78.6 \\
\hline Fair and effective R \& S can lead to employee satisfaction & - & - & - & - & - & - & 3 & 21.4 & 11 & 78.6 \\
\hline
\end{tabular}


The above descriptive analysis also shows that different respondents have given different level of opinion regarding required strategies for effective recruitment and selection practices in banks. Therefore a list of adopted strategies for conducting an effective recruitment and selection practices can be identified based on more than total $50 \%$ percentage of agree and strongly agree statements which are specific and structured recruitment and selection policies should be designed (100\%), huge applicants should be encouraged to apply for filling vacancies (57.2\%), job analysis guides recruitment $(100 \%)$, job analysis should be the prior function (85.7\%), proper job analysis can reduce recruitment and selection cost $(85.7 \%)$, rigorous selection process should be followed $(85.7 \%)$, selection tasks should be fair enough (93.1\%), both line \& HR manager should participate in selection activities as they know better about the job contents $(100 \%)$, managers should spend considerable time in selection process (85.7\%), applicants' psychological attributes should be focused (78.6\%), written recruitment \& selection policies are important to motivate existing employees to stay $(57.1 \%)$, recruitment and selection (R \& S) policies should be updated (92.9\%), R \& S policies should be related with organizational policies and strategic goals (71.4\%), the chosen selection tool must be able to measure an attribute consistently or give consistent scores (78.5\%) and selection contents should be designed based on a job relevant criterion $(73.5 \%)$, specific and structured recruitment and selection policies should be designed (71.4\%), and right employees should be placed in the right position to lead higher performance $(100 \%)$, and fair and effective R \& S can lead to employee satisfaction (100\%).

\section{Discussions}

The study reveals that all banks have written recruitment and selection policies. They completely rely on job analysis information to give job advertisement for filling vacant positions. Majority of the respondent banks discourages the agency involvement in recruitment and selection functions. They mentioned that they give job advertisement publicly when a vacancy occurred. They also stated that their HR departments conduct the total recruitment and selection process in consultation with line management. The participation of line management has been increased over the last three years.

This study has also identified most commonly used recruitment sources which are internal sources, company websites, newspaper advertisement, employee referrals, erecruitment and talent hunting. All banks have significant differences in the level of preferences for using different recruitment sources except internal recruitment, campus recruitment, direct mail to prospective candidates, TV/radio advertisement and walk-ins/write-ins. Though banks are significantly different in adopting different selection strategies for choosing right employees for the vacant positions, there are some commonly used selection strategies like inviting applications along with curriculum vitae, references check, checking biographical data, evaluation of training and experiences, ability tests, knowledge tests, performance test, use of Assessment centres, behavioral interviews, situational interviews, personality and interest test, aptitude tests, face to face interview, medical examination except for group interview. They have a similar level of preferences for selection methods of ability test, assessment centers, personality\& interest test. A comprehensive selection model for the entry-level position has been developed based on the commonly practiced selection process.

Another segment of this paper has revealed that major common barriers for effective R\&S practices are lack of proper human resource planning, availability of fewer qualified applicants, difficulty in detecting qualified applicants, competition for the same applicants, no strong linkage with HR strategy and organizational goals, lack of experiences in recruitment and selection functions, ineffective job analysis, incomplete job advertisement, and cost of recruitment and selection etc. Strategies like designing specific structured and written R\&S policies, encouraging huge applicants, conducting job analysis before recruitment to reduce costs, following rigorous and fair selection process, ensuring both line and HR managers participation, spending considerable time by managers during recruitment and selection tasks, focusing candidates' psychological attributes, updating and integrating $R \& S$ policies with organizational policies and strategic goals, ability of the selection tools to measure consistently and confirming job relevant selection contents are practicing by banks to conduct an effective recruitment and selection activities as reported by them. Therefore, based on above discussions it could also be concluded that banks are following both equity-based and resources based view theory for recruiting new employees.

\section{Conclusion}

The private sector commercial banks of Bangladesh are the most structured organizations as they are continuously developing and updating human resource (HR) policies and practicing those policies properly. Therefore, this paper could be beneficial for their future development. Some recommendations can be drawn based on the above analysis and findings like banks should give more emphasize on internal recruitment not only to increase employee motivation and loyalty but also to reduce external costs of advertising, selection activities, orientation, training and development etc. They also can use the sources of campus recruitment to acquire fresh and energetic employees, direct mail to the top and renowned personnel to obtain the most competent and experienced employees. Sometimes they also can allow walk-ins or write-ins application for the junior level position.

Though all banks have a separate but specific selection 
process, some private banks are practicing too much narrow and some are practicing a too much clumsy process which may not give the effective result. Therefore to ensure effective and efficient performances from entry-level employees' banks can follow the provided comprehensive selection model instead of following a narrow process. Banks can follow those identified strategies for maintaining effective recruitment and selection practices to overcome major barriers to recruiting functions. This paper also can be followed by HR personnel of other manufacturing and service organizations as a descriptive guideline to conduct effective recruitment and selection activities.

This study was restricted by examining the current scenario of different recruitment sources, selection methods and the entry level selection process, perceived barriers to effective recruitment and selection activities, adopted strategies to eliminate those barriers in the private banking sector of Bangladesh. Future research could be enhanced to develop selection model for other later entry-level positions for the banking sector and to show the impact of current practices on overall performances. The study also can be continued to recommend guideline for an effective recruitment and selection practices with examining the current scenario of strategies and practices of other industries in Bangladesh.

\section{References}

[1] Ofori, D. and Aryeetey, M. (2011). Recruitment and selection practices in small and medium enterprises. International Journal of Business Administration, Vol. 2, No. 3, pp. 45-60.

[2] Gamage, A. S. (2014). Recruitment and selection practices in manufacturing SMEs in Japan: An analysis of the link with business performance. Ruhuna Journal of Management and Finance, Vol. 1, No. 1, pp. 37-52.

[3] Storey, J. (1995). Is HRM catching on? International journal of manpower. Vol. 16, No. 4.

[4] Dessler, G. (2013). Human Resource Management, 13th ed., NY: Pearson Prentice-Hall, Upper Saddle River.

[5] Ballantyne, I. (2009). Recruiting and selecting staff in organizations. In Human Resource Management, Oxford: Oxford University Press. ISBN 978-0199-539-37-6.

[6] Ntiamoah, E. B. Abrokwah, E. Agyei-Sakyi, M. Opoku, B. and Siaw, A. (2014). An investigation into recruitment and selection practices and organizational performance. International Journal of Economics, Commerce and Management, Vol. 2, No. 11, pp. 1-11. ISSN 2348-0386.

[7] Werther, W. B. and Davis, K. J. (1993). Human resources and personnel management (4th ed.). New York: McGraw-Hill.

[8] Vencatachellum, I. and Mathuvirin, N. (2010). Investigating HRM practices role towards customer service excellence in the Mauritian Hotel Industry. International Research Symposium in Service Management, August 24-27. ISSN 1694-0938.

[9] Tabassum, A. (2011). The Process of Recruitment and
Selection in a Developing Country: Case Study of a Bank in Bangladesh. ABAC Journal, Vol. 31, No. 1, pp. 55-67.

[10] Fatema, N. (2014). Paradigm Shift of HRM Practices in the Banking Sector of Bangladesh. IOSR Journal of Business and Management, Vol. 16, No. 7 (V), pp. 45-6.

[11] Absar, M. M. N. (2012). Recruitment \& Selection practices in manufacturing firms in Bangladesh. Indian Journal of Industrial Relations, Vol. 47, No 3, pp. 436-449.

[12] Haq, A. Z. M. (2015). Recruitment and Selection Process of a Private Commercial Bank in Bangladesh. American Journal of Service Science and Management, Vol. 2, No. 5, pp. 54-58.

[13] Henry, O. and Temtime, Z. (2009). Recruitment and selection practices in SMEs: Empirical evidence from a developing country perspective. Advances in Management, Vol. 3, No. 2, pp. 52-58.

[14] Stewart, G. L. and Carson, K. P. (1997). Moving beyond the mechanistic model: an alternative approach to staffing for contemporary organizations. Human Resource Management Review, Vol. 7 No. 2, pp. 157-84.

[15] Kepha, O. Mukulu, E. and Waititu, G. A. (2014). The Influence of Recruitment and Selection on the Performance of Employees in Research Institutes in Kenya. International Journal of Science and Research (IJSR), Vol. 3, No. 5, pp. 132-138.

[16] Hsu, Y. R. and Leat, M. (2000). A study of HRM and recruitment and selection policies and practices in Taiwan. International Journal of Human Resource Management, Vol. 11, No. 2, pp. 413-435.

[17] Harris, H., Brewster, C. and Sparrow, P. (2003). International Human Resource Management, CIPD, London.

[18] Wickramasinghe, V. (2007). Staffing practices in the private sector in Sri Lanka. Career Development International, Vol. 12, No. 2, pp. $108-128$.

[19] Sinha, V. and Thaly, P. (2013). A review on changing trend of recruitment practice to enhance the quality of hiring in global organizations. Management, Vol. 18, No. 2, pp. 141-156.

[20] Breaugh, J. A. and Starke, M. (2000). Research on Employee Recruitment: So Many Studies, So Many Remaining Questions. Journal of Management, Vol. 26, No. 3, pp. 405-434.

[21] Montan, H. and Charnou, B. (2002). Human resource practices and firm performance of multinational corporations: Influences of country of origin. Journal of International Human Resource Management, Vol. 9, pp. 632-652.

[22] Zottoli M. A. and Wanous J. P. (2001). Recruitment source research: current status and future directions, Human Resource Management Review, Vol. 10, No. 4, pp. 353-382.

[23] Chapman, D. and Webster, J. (2003). The use of technologies in the recruiting, screening, and selection processes for job candidates. International Journal of Selection and Assessment, Vol. 11, pp. 113-20.

[24] Carless, S. A. (2007). Graduate recruitment and selection in Australia. International Journal of Selection and Assessment, Vol. 15, No. 2, pp. 153-66.

[25] Tayeb, M. (1995). Organizations and national culture: methodology consideration. Organization Studies, Vol. 14, pp. 429-46. 
[26] István, J. (2010). Selection methods used in recruiting sales team members. Periodica Oeconomica, October, pp. 110-117.

[27] Compton R. L., B. Morrissey, and N. A. Nankervis. (2014). Effective Recruitment and Selection Practices. Australia: $\mathrm{CCH}$ Australia Limited. ISBN: 978-1-925091-15-1.

[28] El-Kot, G. and Leat, M. (2008). A survey of recruitment and selection practices in Egypt. Education, Business and Society: Contemporary Middle Eastern Issues, Vol. 1, No. 3, pp. 200212 .

[29] Moscoso, S. (2000). Selection interview: a review of validity evidence, adverse impact and applicant reactions. International Journal of Selection and Assessment, Vol. 8 No. 4, pp. 237-47.

[30] Stewart, J. and Knowles, V. (2000). Graduate recruitment and selection practices in small businesses. Career Development International Review, Vol. 5, No. 1, pp. 21-38.

[31] Heraty, N. and Morley, M. (1998). In search of good fit: policy and practice in recruitment and selection in Ireland. Journal of Management Development, Vol. 17 No. 9, pp. 662 85 .

[32] Van Vianen, A. E., Taris, R., Scholten, E., and Schinkel, S. (2004). Perceived fairness in personnel selection: Determinants and outcomes in different stages of the assessment procedure. International Journal of Selection and Assessment, Vol. 12, No. 1-2, pp. 149-159.

[33] Zhu, C. J. and Dowling, P. J. (2002). Staffing practices in transition: some empirical evidence from China. International Journal of Human Resource Management, Vol. 13 No. 4, pp. 569-97.

[34] Budhwar, P. and Sparrow, P. (2002). An integrative framework for determining cross-national human resource management practices. Human Resource Management Review, Vol. 12, pp. 377-403.

[35] Barber, A., Wesson, M., Roberson, Q. and Taylor, S. (1999). A tale of two job markets: organizational size and its side effects on hiring practices and job search behavior. Personnel Psychology, Vol. 52 No. 4, pp. 841-67.

[36] Vigoda, E. (2000). Organizational politics, job attitudes, and work outcomes: Exploration and implications for the public sector. Journal of vocational Behavior, 57 (3), 326-347.

[37] Unwin, K. (2005). Recruiting knowledge workers. HRM Review, Vol. 5, No. 10, pp. 5-9.

[38] Okoh, A. O. (2005). Personnel and human resources management in Nigeria. Lagos: Amfitop Books.

[39] Bohlander, G., Snell, S. and Sherman, A. (2001). Managing human resources. New YorkSouth- Western College.

[40] Terpstra, E. D. and Rozell, J. E. (1993). The relationship of staffing practices to organizational level measures of performance Personnel Psychology, Vol. 46, No. 1, pp. 27-48.
[41] Sarkar, A. and Kumar, S. (2007). Effective recruitment and selection: An approach towards model building. HRM Review, Vol. 7, No. 7, pp. 15-22.

[42] Osemeke, M. (2012). The impact of human resource management practices on organizational performance: A study of Guinness Nigeria Plc. International Journal of Arts and Humanities, Vol. 1, No. 1, pp. 79-94.

[43] Oladele, P. O. and Akeke, N. I. (2012). Effect of Customer Satisfaction on Customer on Customer Loyalty among Selected Bank Customers in Ado-Ekiti Metropolis, Nigeria. Interdisciplinary Journal of Contemporary Research in Business, Vol. 3, No. 11

[44] Ifill, S. and Moreland, N. (1999). Auditing recruitment and selection using generic benchmarking: a case study. The TQM Magazine, Vol. 11, No. 5, pp. 333-41.

[45] Jameson, S. M. (2000). Recruitment and training in small firms. Journal of European Industrial Training, Vol. 24, No. 1, pp. 43-9.

[46] Kaplan, R. S. and Norton, David P. (2004). Measuring the Strategic Readiness of Intangible Assets. Harvard Business Review, Vol. 82, No. 2, pp. 52-64.

[47] Dess, Gregory, G. and Jason, D. Shaw (2001). Voluntary turnover, social capital, and Organizational performance. Academy of Management Review, Vol. 26, No. 3, pp. 446456.

[48] Adams, J. S. (1963). Toward an understanding of equity. Journal of Abnormal and Social Psychology, Vo. 67, pp. 422434.

[49] Barney, J. B. (2001). Resource-based theories of competitive advantage: a ten-year retrospective on the resource-based view. Journal of Management, Vol. 27, No. 6, pp. 643-650.

[50] Boxall, P. (1996). The Strategic HRM Debate and the Resource-Based View of the Firm. Human Resource Management Journal, Vol. 6, No. 3, pp. 59-75.

[51] Deshpande, S. and Golhar, D. Y. (1994). HRM practices in large and small manufacturing firms: A comparative study. Journal of Small Business management, Vol. 32, No. 2, pp. 49-56.

[52] Priyanath, H. M. S. (2006). Managerial deficiencies in the small and medium enterprises (SMEs) in Sri Lanka: An empirical evidence of SMEs in the Ratnapura District. Sabaragamuwa University Journal, Vol. 6, No. 1, pp. 93-105.

[53] Stanley E. G. and Gregory M. M. (2001). Achieving World Class Supply Chain Alignment: Benefits, Barriers and Bridges. A Compiled Research Report.

[54] Kothari, C. K. (2011). Research Methodology: Methods and Techniques. (2nd Revised Edition) New Age International Publishers, New Delhi. 